\title{
An Evaluation on Application Field of RFID in Container Terminal by ANP
}

\author{
+ Hyun Kim* \\ * Professor, College of Port \& Logistics, Tongmyung University, Busan 608-711, Korea
}

\begin{abstract}
As the era of ubiquitous has come, it is able to have more convenient and efficient operation system since many efforts have devoted to developing an appropriate operation system in the ubiquitous environment and applying RFID/USN technology to various parts in the industry. Also, the port logistics area has considered RFID/USN to develop more efficient port logistics environment and improve their efficiency. Therefore, this study investigates current trends of RFID technology and application cases in the port logistics area since RFID stands in the important position of changes of maritime port environment. This study tries to find possible areas for applying RFID technology and analyze expected effects when RFID is adopted those areas. Lastly, the priority level among the possible RFID application fields in the container terminal has been evaluated by experts' survey.
\end{abstract}

Key words : ANP(Analytic Network Process, AHP(Analytic Hierachy Process), Analysis, Container terminal, Productivity, RFID, $U$-port

\section{Introduction}

In the 21 century, a mega-port has been developed all over the world and a concept of automated container terminal also has been adopted to support a hinterland development, high speed achievement and economic development. The purpose of these efforts are to attract a super post panamax and provide better service under fierce competition environment. Actually, some of world major ports have constructed automated container terminal and it is already serving their customers. In fact, developing automated container terminal is current world trends. Therefore, transferring existed container terminals to automated container terminal is focusing on berth and yard area to be automatized. These areas are able to improve productivity and system as fully automatized (Kim and Nam, 1998; Hong and Chung, 2003; Tao, 1999; Gribson et al., 1996). Recently, there are an attempt to apply RFID technology to container terminal gate for automatic recognition of vehicle and container. In the meantime, there is efforts to legislate for e-Seal adaptation by US custom in 2007, established standard technology related to RFID by ISO and activities for standardization by WSC's RFID working group and ISO. According to these movements, e-Seal related standardization will be established as US leads. Moreover, Seal Verification Rule of US custom has been made out its draft in 2006 and it will be applied from 2007 since it is considered that it may effect to all over the maritime industry. Once it starts, all the containers which is traveling to US may attach the e-Seal compulsorily. After activated Seal Verification Rule, containers may go to the port which is able to verify attachment/detachment of $\mathrm{e}$-Seal. Therefore, construction of RFID infrastructure is surely necessary.

As RFID environments are rapidly spread, we also needed to cope with this trends, especially in maritime port logistics area(Kim et al., 2004). Therefore, various areas in maritime port logistics have tried to adopt RFID. Some of particular areas and expected functions can be listed 1) automatic recognition of vehicles and containers at the gate of container terminal 2) elevating security and clearance to achieve reliability and rapidity, 3) improving yard space utilization and rehandling ratio through achieving container information before entering the gate, 4) improving productivity of loading/unloading at the berth and other facilities(Kim and Kim, 2006).

In this paper, we study a domestic case of RFID adaptation in the port area and a current situation of other countries. We also evaluate the RFID application field based on container terminal operation system and network structure between evaluation criteria and evaluation detailed items which could be carried out by ANP analysis. Moreover, the container terminal operation system is consist of a gate system, shipment system and inland connection system. On the other hand, terminal productivity, economic efficiency, service level and technology application are considered as evaluation criteria of ANP analysis.

† Corresponding Author: Hyun Kim, hyunkim@tu.ac.kr, 011-891-6402 


\section{The trends of RFID technology}

\section{1 Application field of RFID}

Main application area can be varied such as logistics and distribution management, security, access control, tracing people and animal, collecting charges, preventing counterfeit note and so on. Especially, distribution area is expected to have far reaching effects of RFID. For instance, if department store saves information of customer's taste by CRM, then a wireless tag that has been attached on the product, that may be attractive to customer, delivers customer product information by PDA or mobile automatically when the customer passes by certain store in the department store.

However, the price of RFID tag is much expensive than other sensing equipment. So, to put to practical use of RFID, it needs to lower the price. Another problem is that it should use same radio frequency in the logistics area to use of wireless resources.

Table 1 Application field by frequency range

\begin{tabular}{|c|c|}
\hline $\begin{array}{l}\text { Range of } \\
\text { frequency }\end{array}$ & Application field \\
\hline$>135 \mathrm{kdh}$ & $\begin{array}{l}\text { Using for access control, animal recognition, tracking and } \\
\text { so on, possible to use without permission }\end{array}$ \\
\hline 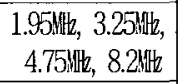 & $\begin{array}{l}\text { Using for retail store's EAS(Electronic Articles } \\
\text { Surveillance) system }\end{array}$ \\
\hline 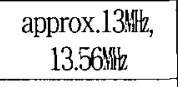 & EAS system \& ISM(Industrial, Scientific, Medical) \\
\hline approx. 27int & ISM application \\
\hline $430 \sim 460:$ itte & ISM application in zone $1 *$ \\
\hline $902 \sim 916$ 鼎 & ISM application in zone $2 *$ \\
\hline 918 926:1tz & RFID transmitter application in Australia \\
\hline $2,350 \sim 2,450$ 促 & ISM frequency range using all over the world \\
\hline $5,400 \sim 6,800$ : & Assigning for future use \\
\hline
\end{tabular}

* In US, using for various applications depending on priority, dividing to narrow and wide band source, zone 1 is GSM telephone network.

\subsection{Current situation of RFID standardization}

\section{1) Propulsion trend for standardization}

As seen it before, there is a problem that it should use of same radio frequency all over the world in usage of logistics RFID application. For this reason, ISO is trying to standardize various technologies of RFID and apply this technologies with new other technologies as well. Those trials are appeared in $\mathrm{B} 2 \mathrm{~B} / \mathrm{B} 2 \mathrm{C}$ which is for electronic payment by RFID, then RFID can be gearing with network to perform this job. Moreover, there is a study about interface to link EPC that is standard index number and
IPv6 that is standard internet.

At present, a process of RFID ISO standardization which performs on worldwide is on stage of completion. If we differentiate our RFID technology by improving the recognizing distance of RFID, developing the small size of RFID tag, lowering the price and those kinds of technology developments, we may be able to achieve the competitive power.

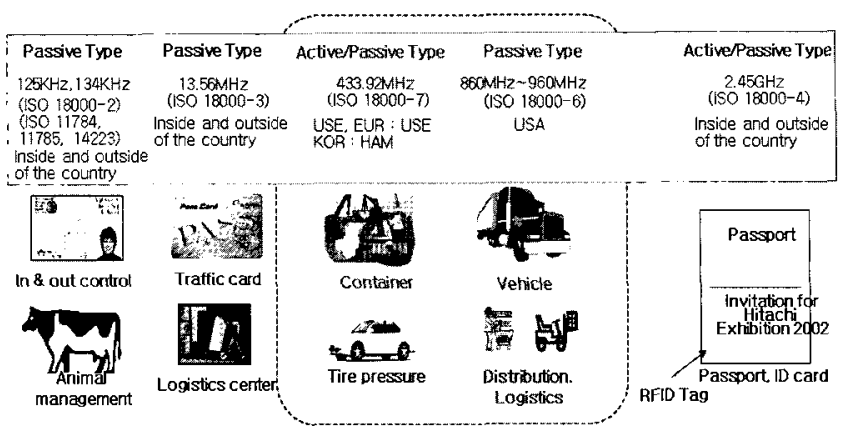

Fig. 1 Status of international standardization by RFW's tag frequency

2) Major current situation of RFID tag for container (433MHz frequency range)

US Federal Communications Commission(FCC) decided to choose $433 \mathrm{MHz}$ frequency range as dedicated to active RFID tag for containers that are carried into US because it is possible to recognize a long distance and trace containers in real-time. In addition, the internal humidity and external impact on containers can not bother the sensing. This RFID active tag carries a battery itself, therefore it is appropriate to logistics business which needs the long distance communications. Active RFID tag in $433 \mathrm{MHz}$ frequency will be a standard of container recognition in the US and Europe.

Table 2 Communication's parameters of ISO/IEC $18000-7$ reader/tags

\begin{tabular}{|c|c|c|}
\hline Parameter & reader $\rightarrow$ tag & tag $\rightarrow$ reader \\
\hline active frequency & \multicolumn{2}{|l|}{ 433.921ltz } \\
\hline accuracy of action frequency & \multicolumn{2}{|l|}{$+/-20 \mathrm{ppm}$} \\
\hline Length of occupied chanel & 500:Hilz & 200 ante \\
\hline $\begin{array}{c}\text { Max. transmission EIRP } \\
\text { (Equivalent Isotropically Radiated Power) }\end{array}$ & \multicolumn{2}{|c|}{$\begin{array}{l}5.6 \mathrm{dBm} \text { (Max Electronic Power) or } \\
\text { country regulation }\end{array}$} \\
\hline Spurious emission & \multicolumn{2}{|c|}{$\begin{array}{l}\text { In band : } N / A \\
\text { Out of band : depending on country } \\
\text { regulation }\end{array}$} \\
\hline Spectrum mask & \multicolumn{2}{|c|}{$\mathrm{N} / \mathrm{A}$} \\
\hline Modulation & \multicolumn{2}{|c|}{ FSK (Frequency Shift Keying) } \\
\hline Bit Rate & \multicolumn{2}{|l|}{$27.7 \mathrm{kbps}$} \\
\hline Bit Rate Accuracy & \multicolumn{2}{|l|}{$200 \mathrm{ppm}$} \\
\hline
\end{tabular}

* ISO/IEC 18000-7: Information technology Radio frequency identification for item management Part 7: Parameters for active air interface communications at 433 纤 Adopting 'Narrow Band' by active tag 
3) Major current situation of RFID tag for $e^{-S e a l}$ (433M位 frequency range)

It has been discussing to adopt standard $433 \mathrm{MHz}$ frequency range of ISO 18185(Electronic seals for freight containers) and ISO/IEC 18000-7 RFID tag for container e-Seal. To protect the loaded product in the container, 433 $\mathrm{MHz}$ e-Seal tag can send security alarm and record the history of situation when the containers are abnormally opened and closed.

4) Major current situation of RFID tag for vehicle (900Mtz frequency range)

RFID tag of $900 \mathrm{MHz}$ frequency range is able to recognize the vehicle which moves with speed of $50 \mathrm{~km} / \mathrm{hr}$ in the long distance. Especially, RFID active tag which has attached battery is proper to the business which needs the long distance communication such as logistics, therefore this radio frequency range is recommended to use in logistics field. Korea decided to use 908.5 914 $\mathrm{MHz}$ that had been used for 'city phone' in the past, now for logistics and distribution business. Using 900MHz zone of RFID has been adopted to use in various areas and also it is applying for show business that Korea government involved.

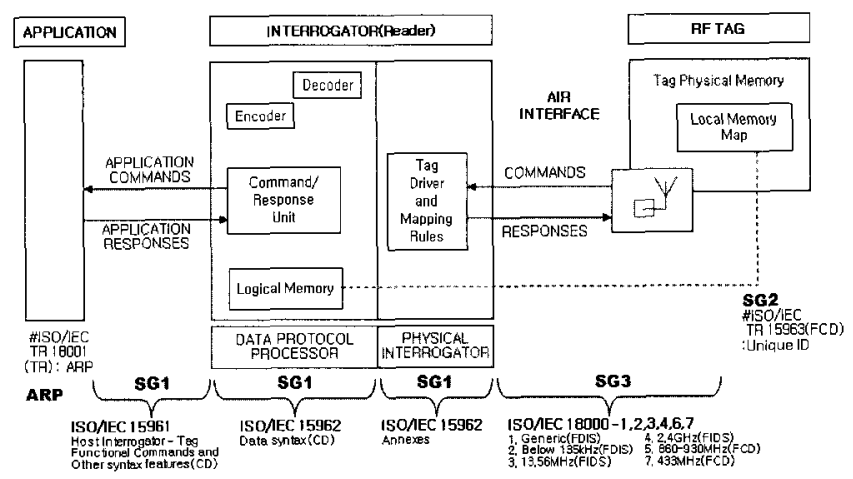

Fig. 2 Standardization framework of RFID system

\section{Current situation of RFID applied container terminal business}

\subsection{Business for improving efficiency of port logistics based RFID}

Many countries who are a competitor of Korea try to reinforce their logistics competitiveness through using the technology of RFID and wireless network. Korea government, in this situation, has run a RFID show business from 2005 with a slogan of being a logistics hub in Northeast Asia and improving competitive power in transportation business. The goal of this business is to strengthen our position as a logistics hub in Northeast Asia with 1) providing a function of tracing container location through container automatic recognition, 2) intensifying port competitiveness by improving efficiency of port terminal operation and 3) constructing the shipping and port import/export containers' information infrastructure through improvement of environment of port logistics information technology. Additional effects can be expected that establishing foundation of automatization of port logistics, achieving RFID technology model, creating new demand, and increasing visibility about containers' location.

Especially, for the port logistics area, this business will be contributed to build a foundation of fully automated system in the future since it has some expected businesses such as inspecting container vehicle in the realtime, automatization process of carry in/out at the Gate, increasing work productivity by reducing information checking time and error management, realtime container checking and so on. Actually, this business is expected to be successful case by verified technology. It may be able to achieve a RFID model in port logistics area. If RFID technology can be spread into the market, then next business opportunity may come. It means that RFID demand in intemal industry can be generated, Additionally, it may be possible to generate demand in private logistics that connect to RFID infrastructure of national logistics and build a foundation environment for higher technology of RFID.

Lastly, it may increase a visibility of container location from ICD(Inland Container Depot) to overseas port handling since it can provide container location realtime tracing and reduce the time to figure out whereabouts the container in the logistics foothold.

\subsection{Secure global logistics chain in USA}

After 9.11 terror in USA, many countries try to construct a secure global logistics chain since people recognized that it is needed to expand own secure program and keep economic stability, therefore, the best way to avoid a threat of cargo terrorism and cargo related crime can be using a concept of JT(Just In Time). However, it needs more effective cargo security technology because the reporting system for cargo theft is not strong enough and current law of transportation related crime prosecution is also weak. Another issue is lack of understanding and education about essence of cargo crime. There are restrictions to consider, such as no standardization, integration of complicated systems, international political issue and government guarantee and approval. Therefore, as US 
leads, it is materialized with three projects C-TPAT (Customs-Trade Partnership against Terrorism), SST(The Smart and Secure Trade lanes) and CSI(Container Security Initiatives).

1) C-TPAT(Customs-Trade Partnership against Terrorism)

It is planned to be able to receive and control the information which is overall supply chain including an event of the product which is in process of transportation or the role of provider. It needs an education and training about recognizing transportation security related matter, access control and complete self-inspection which is including process security, personal security and so on.

It is able to provide a high level security since C-TPAT is related to build a cooperative relationship between government-company for overall supply. chain and border security, and customhouse cooperates with final importer, transporter, broker, producer and other parties. Customhouse can request firms and business partners who are in the supply chain to follow the principle that guides security. To ensure security of overall supply chain, it is necessary to adopt RFID to develop the those security program according to C-TPAT guide.

2) SST(The Smart and Secure Trade lanes)

It is an agreement among PSA, P\&O, HutchisonShampoa Ltd. and other contributors those who manage over $70 \%$ of containers all over the world that they adopt such kind of automatic tracing, sensing and security technology to the containers which travel from US port to overseas ports. It uses wireless recognition and sensor, and applied to Washington July 2002 as a first run, then extended use to New Jersey, New York.

SST that has been used in DoD(Department Of Defense) for several years is based on RFID technology, it started applying RFID to port area which was often pointed out as weakest security area in US and expanded TAV(Total Asset Visibility) network linking through 36 countries to support DoD that works for recognizing thousands of containers in the real-time and tracing containers by location data. This system has several functions; a tag that is not interrupted by system, an alarm that rings when the event occurs, simulated inspection and approved tracing. Savi Technology, Inc: TAV Network (Network that provides cargo container tracing system by RFID) is a major solution provider for construction and operation. This system has a procedure providing reporting to custom office directly, tracking position and financial management program when the $\mathrm{e}^{-}$Seal is destroyed, terror occurs or there is an illegal possibility that might happen. Fig. 3 and Fig. 4 shows SST transportation in the process (U.S. customs, 2007) and indicates application procedure of core technology of $\mathrm{e}^{- \text {Seal }}$ (Ministry of Maritime Affairs and Fisheries, 2005).

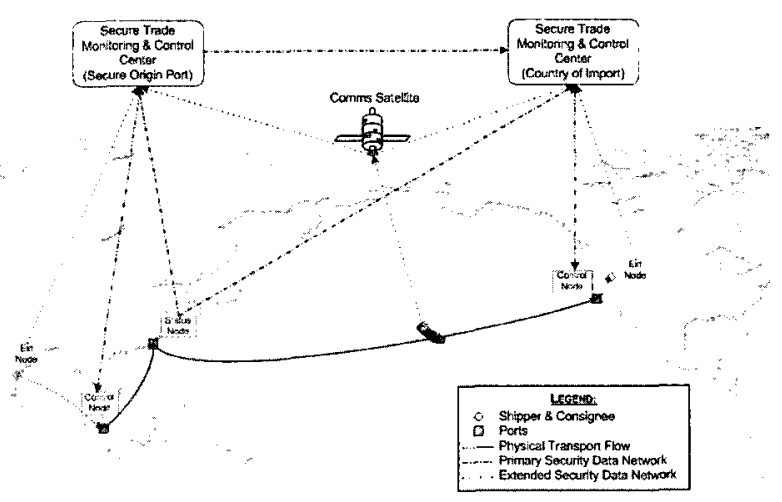

Fig. 3 Transport process of the Smart and Secure Trade lanes(SST)

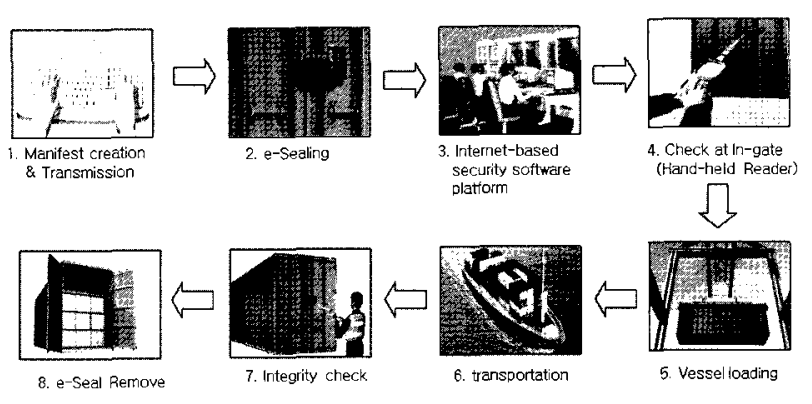

Fig. 4 e-Seal working process

\section{3) CSI(Container Security Initiatives)}

CSI is a preliminary activity by customs, this activity is connected with observing sea containers before they enter the USA. It also indicates overall efforts to protect their border against risks that may infiltrate through commercial cargo volumes. The purpose of this program is to establish security guide for distinguishing high level of dangerous containers and then give them rapid preliminary inspection by RFID before they enter the US port. For this performance, the use of Smart and Secure Container based on RFID system has been suggested to develop.

Those world ports who satisfy this condition keep involving in CSI international agreement with US customs, to exchange information about terror suspects and dangerous cargos and ensure the security of trade supply chain since 9.11 disaster. Busan port and other mega-port in Korea have joined CSI and Fig. 5 shows ports who have registered for CSI( US customs, 2007; http://www.cbp.gov). 


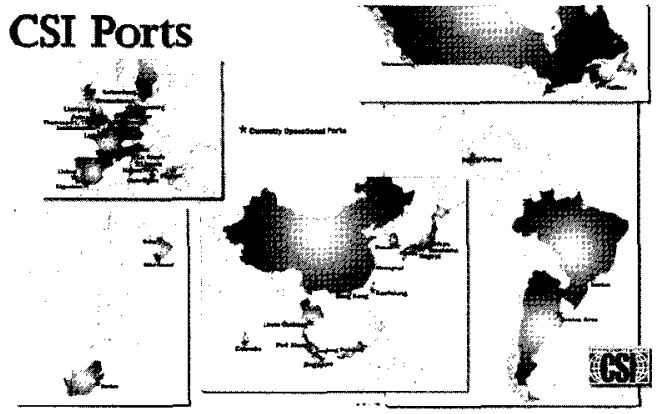

Fig. 5 Contracting port of Container Security Initiatives(CSI)

\section{Evaluation of RFID application field in the terminal by ANP}

\subsection{Study of theoretical background of ANP}

People usually perform a decision-making process with limited information. Since collected information can be quite subjective, there are many invisible information that is difficult to evaluate and measure. To make up for weak point in the decision-making process, AHP (Satty, 1980) was developed in 1980. AHP is a method to find out an optimal alternative by organizing a decision-making problem according to hierarchy structure(Fig. 6). Especially, AHP can provide a problem structure and scheme, a frame of comprehensive decision-making, a logical consistency, sensitivity analysis changes by information and situation and lastly convenience. Therefore, it is preferred method among researchers. Internally, it has increased the number of researches that adopted AHP to their study since KDI used AHP for multi-criteria analysis when they evaluate overall preliminary validity survey. However, it is difficult to make a structure or scheme when the decision-making problem contains too many factors and the dependency among the factors is too high. The assumption that the factors in every hierarchy and between hierarchy are all independent each other is not reasonable since the independency among the factors are existed in the reality.

ANP has been seriously studied from 2000. This method provides an optimal solution which approaches nearly real situation under complicated decision-making environment that includes interdependency in the hierarchy structure(Hamalainen et al., 1986). AHP illustrates an interdependency in each hierarchy only in a one-way, unlikely ANP is possible to describe the interdependency in a two-way arcs(refer to Fig. 7 ). For instance, in a decision-making process, ' $\mathrm{A} 1$ ' and ' $\mathrm{A} 2$ ' are in a casual relationship each other and ' $\mathrm{A} 2$ ' and ' $\mathrm{A} 3$ ' are in a casual relationship each other. In this conditions, AHP cannot measure the relationship between ' $\mathrm{A} 1$ ' and 'A3', though it is intuitively predicted this relationship. However, ANP can figure out these intuitive relationship by network structure (Lee et al., 2004).

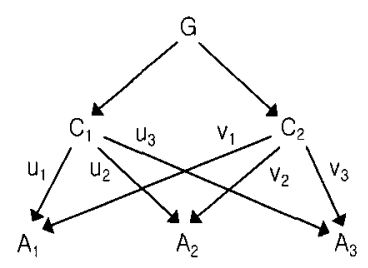

Fig. 6 Hierarchy

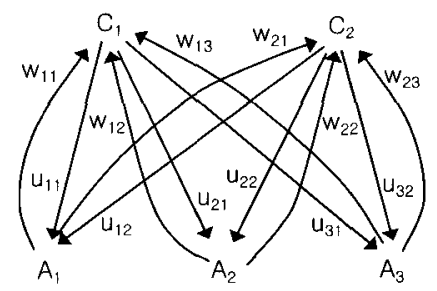

Fig. 7 Inter-evaluation

structure of ANP
Generally, ANP has following 5 steps (Mead and Sarkis, 2002)

(1) Drawing a decision-making network that shows relationships among decision-making factors (structuring ANP model).

(2) Running pair-wise comparison between factors in each hierarchy.

(3) Calculating relative priority among the factors and drawing each sub-matrix.

(4) Assigning all the factors into a matrix, then drawing super-matrix that has a column vector as priority of each factor. Note that there are two ideas about probabilistic character. Saaty(1996) gave the priority value to every column differently and make it ' 1 ' when they are summed up. Mead and Sarkis(2002) proposed to divide relative priority of factors that consist of that column by sum of each column.

(5) Computing convergency priority by $(\mathrm{k}+1)$ times cumulative multiply of super-matrix.

4.2 ANP model and analyzing plan for evaluation of RFID application field

1) ANP model for deriving RFID application field

To figure out evaluation criteria for applying RFID to container terminal, this study has examined various possible evaluation criteria referred from criteria of container terminal which has been chosen to perform RFID show business and criteria of applying automatic container terminal.

First of all, the evaluation criteria that have been considered in many prior researches for developing automated container terminal are terminal productivity (including efficiency, effectiveness), economic propriety, financial propriety, cost benefit estimation, service level, technology application and application possibility. Among them, economic propriety, financial propriety and cost 
benefit estimation have been unified to economic efficiency(KDI, 2000). Moreover, although terminal productivity generally includes the meaning of efficiency and effectiveness or uses as same meaning of them, our study gave a limitation of this term as productivity since it is often used in the container terminal. Besides, we include service level(service quality) which is non-quantitative evaluation criteria and technology application that may relate to expanding use of $\mathrm{RFI}$ in the internal/external terminal and RFID standardization. The ANP model that this study suggests to use for evaluating RFID application field in the container terminal has been shown in Fig. 8.

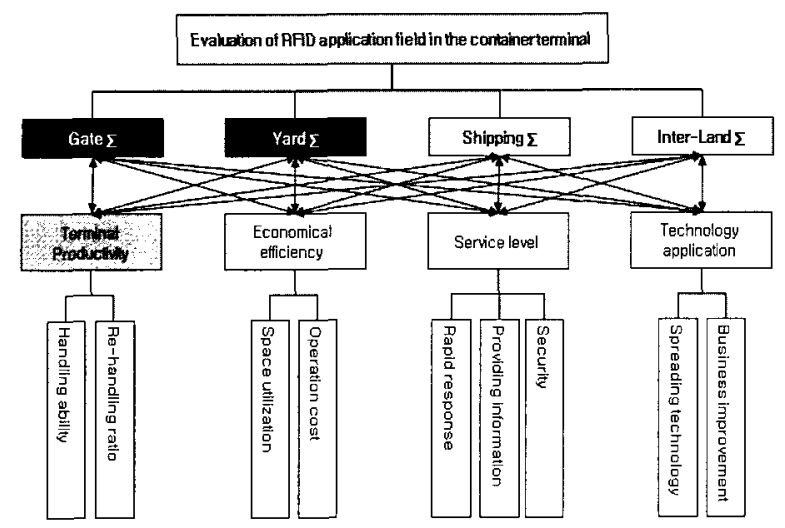

Fig. 8 Research model of Inter-evaluation structure

\section{2) Survey plan}

This study has constructed ANP model based a geometrical average value which was carried out from survey result applied to 21 experts who are working in maritime logistics research, port logistics IT, and terminal operation. Additionally, it performed double checking on survey questionnaires by RFID show business and automatic container terminal criteria and interviewing experts for raising accuracy of survey.

\subsection{Evaluation of RFID application field by ANP analysis}

\section{1) Generating sub-matrix}

Super-matrix that is for ANP analysis consists of priority of each sub-matrix. Followings explain the particular procedure.

First, it needs to calculate priority of each system; Gate system, yard system, shipment system and inland connection system. Table 3 shows priority of the case of Gate system, and it marked that $52.4 \%$ for terminal productivity, $20.0 \%$ for economic efficiency, $18.4 \%$ for service level and 9.2\% for technology application.

Table 3 Relative priorities with respect to Gate system

\begin{tabular}{c|c|c|c|c|c}
\hline Gate system & $\begin{array}{c}\text { Terminal } \\
\text { productivity }\end{array}$ & $\begin{array}{c}\text { Economical } \\
\text { efficiency }\end{array}$ & $\begin{array}{c}\text { Service } \\
\text { level }\end{array}$ & $\begin{array}{c}\text { Technology } \\
\text { application }\end{array}$ & Priority \\
\hline $\begin{array}{c}\text { Teminal } \\
\text { productivity }\end{array}$ & 1.000 & 3.898 & 3.240 & 3.786 & 0.524 \\
\hline $\begin{array}{c}\text { Economical } \\
\text { efficiency }\end{array}$ & 0.257 & 1.000 & 1.652 & 2.306 & 0.200 \\
\hline Service level & 0.309 & 0.605 & 1.000 & 3.122 & 0.184 \\
\hline $\begin{array}{c}\text { Technology } \\
\text { application }\end{array}$ & 0.264 & 0.434 & 0.320 & 1.000 & 0.092 \\
\hline
\end{tabular}

Table 4 is the result of each areas' priority in the container terminal and it was calculated by identical way as Gate system. Although it shows somewhat differences by each area, it analyzed a rank of priority for adopting RFID approximately that is terminal productivity, economic efficiency, service level and technology application in order.

Table 4 Relative priorities with respect to RFID's field

\begin{tabular}{c|c|c|c|c}
\hline Classification & $\begin{array}{c}\text { Gate } \\
\text { system }\end{array}$ & $\begin{array}{c}\text { Yard } \\
\text { system }\end{array}$ & $\begin{array}{c}\text { Shipment } \\
\text { system }\end{array}$ & $\begin{array}{c}\text { Inland connection } \\
\text { system }\end{array}$ \\
\hline $\begin{array}{c}\text { Teminal } \\
\text { productivity }\end{array}$ & 0.524 & 0.556 & 0.588 & 0.498 \\
\hline $\begin{array}{c}\text { Economical } \\
\text { efficiency }\end{array}$ & 0.200 & 0.183 & 0.162 & 0.163 \\
\hline \begin{tabular}{c} 
Service level \\
\hline $\begin{array}{c}\text { Technology } \\
\text { application }\end{array}$
\end{tabular} & 0.184 & 0.165 & 0.152 & 0.216 \\
\hline Total & 1.000 & 1.000 & 1.000 & 1.000 \\
\hline
\end{tabular}

Secondly, the priority of RFID application field has to be calculated according to evaluation criteria. Table 5 shows the priority of application field when the terminal productivity is only considered; Gate system 50.1\%, yard system 21.9\%, shipment system $17.2 \%$ and inland connection system $10.8 \%$ in order.

Table 5 Reative priorities with respect to teminal productivity

\begin{tabular}{c|c|c|c|c|c}
\hline $\begin{array}{c}\text { Terminal } \\
\text { productivity }\end{array}$ & $\begin{array}{c}\text { Gate } \\
\text { system }\end{array}$ & $\begin{array}{c}\text { Yard } \\
\text { system }\end{array}$ & $\begin{array}{c}\text { Shipment } \\
\text { system }\end{array}$ & $\begin{array}{c}\text { Iland connection } \\
\text { system }\end{array}$ & Priority \\
\hline Gate system & 1.000 & 3.304 & 3.730 & 2.833 & 0.501 \\
\hline Yard system & 0.303 & 1.000 & 1.878 & 2.303 & 0.219 \\
\hline Shipment system & 0.268 & 0.533 & 1.000 & 2.675 & 0.172 \\
\hline $\begin{array}{c}\text { Inland connection } \\
\text { system }\end{array}$ & 0.353 & 0.434 & 0.374 & 1.000 & 0.108 \\
\hline
\end{tabular}

Table 6 is the result of the priority of RFID application field in the terminal by evaluation criteria. It concluded that 
generally, Gate system, yard system, shipment system and inland connection system considered in order.

Table 6 Relative priorities with respect to evaluative criteria of RFID

\begin{tabular}{c|c|c|c|c}
\hline Classification & $\begin{array}{c}\text { Teminal } \\
\text { productivity }\end{array}$ & $\begin{array}{c}\text { Economical } \\
\text { efficiency }\end{array}$ & Service level & $\begin{array}{c}\text { Technology } \\
\text { application }\end{array}$ \\
\hline Gate system & 0.501 & 0.489 & 0.459 & 0.527 \\
\hline Yard system & 0.219 & 0.233 & 0.226 & 0.219 \\
\hline Shipment system & 0.172 & 0.170 & 0.186 & 0.145 \\
\hline $\begin{array}{c}\text { Inland connection } \\
\text { system }\end{array}$ & 0.108 & 0.108 & 0.128 & 0.109 \\
\hline Total & 1.000 & 1.000 & 1.000 & 1.000 \\
\hline
\end{tabular}

2) Consisting initial Super-matrix and creating convergent Super-matrix

This study considered relationship between each system and evaluation criteria rather than interrelation between RFID application fields and between evaluation criteria. Therefore, this study assumed that interrelationship between RFD application field and evaluation criteria can be considered but there is no interrelationship between RFID application fields or between evaluation criteria themselves. With these assumptions, $8 \times 8$ initial super-matrix $(\mathrm{W})$ has been composed basis of sub-matrix in Table 4 and Table 6 . The initial super-matrix is appeared in Table 7.

Table $78 \times 8$ Supermatrix $(W)$

\begin{tabular}{|c|c|c|c|c|c|c|c|c|}
\hline $\begin{array}{l}\text { Super } \\
\text { matrix }\end{array}$ & $\begin{array}{c}\text { Gate } \\
\text { system }\end{array}$ & $\begin{array}{c}\text { Yard } \\
\text { system }\end{array}$ & $\begin{array}{l}\text { Shipment } \\
\text { system }\end{array}$ & $\begin{array}{l}\text { Inland } \\
\text { connection } \\
\text { system }\end{array}$ & $\begin{array}{c}\text { Terminal } \\
\text { productivity }\end{array}$ & $\begin{array}{l}\text { Economical } \\
\text { efficiency }\end{array}$ & $\begin{array}{c}\text { Service } \\
\text { level }\end{array}$ & $\begin{array}{l}\text { Technology } \\
\text { application }\end{array}$ \\
\hline Gate system & 0.000 & 0.000 & 0.000 & 0.000 & 0.501 & 0.489 & 0.459 & 0.527 \\
\hline Yard system & 0.000 & 0.000 & 0.000 & 0.000 & 0.219 & 0.233 & 0.226 & 0.219 \\
\hline $\begin{array}{l}\text { Shipment } \\
\text { system }\end{array}$ & 0.000 & 0.000 & 0.000 & 0.000 & 0.172 & 0.170 & 0.186 & 0.145 \\
\hline $\begin{array}{l}\text { Inland } \\
\text { connection } \\
\text { system }\end{array}$ & 0.000 & 0.000 & 0.000 & 0.000 & 0.108 & 0.108 & 0.128 & 0.109 \\
\hline $\begin{array}{l}\text { Teminal } \\
\text { productivity }\end{array}$ & 0.524 & 0.556 & 0.588 & 0.498 & 0.000 & 0.000 & 0.000 & 0.000 \\
\hline $\begin{array}{c}\text { Economical } \\
\text { efficiency }\end{array}$ & 0.200 & 0.183 & 0.162 & 0.163 & 0.000 & 0.000 & 0.000 & 0.000 \\
\hline Service level & 0.184 & 0.165 & 0.152 & 0.216 & 0.000 & 0.000 & 0.000 & 0.000 \\
\hline $\begin{array}{l}\text { Technology } \\
\text { application }\end{array}$ & 0.092 & 0.096 & 0.098 & 0.124 & 0.000 & 0.000 & 0.000 & 0.000 \\
\hline
\end{tabular}

When it multiplies initial matrix itself $\mathrm{k}$ times repeatedly, it converges into certain regular value. This value is the relative weight value of each field and criteria. In this study, initial super-matrix has been multiplied more than 4 times, and then it generated matrix that has a convergent value as shown in Table 8 . This result indicates the priority of each field and evaluation criteria. The result showed $49.4 \%$ for Gate system, $22.3 \%$ for yard system, $17.2 \%$ for shipping system and $11.2 \%$ for inland connection system are applicable for applying RFID. In addition, the criteria for evaluating RFID application field show the result $53.9 \%$ for terminal productivity, $18.6 \%$ for economic efficiency, $17.8 \%$ for service level, $9.7 \%$ for technology application are important.

Table 8 Convergent Supermatrix(W4) after four times iteration

\begin{tabular}{c|c|c|c|c|c|c|c|c}
\hline $\begin{array}{c}\text { Super } \\
\text { matrix }\end{array}$ & $\begin{array}{c}\text { Gate } \\
\text { system }\end{array}$ & $\begin{array}{c}\text { Yard } \\
\text { system }\end{array}$ & $\begin{array}{c}\text { Shipment } \\
\text { system }\end{array}$ & $\begin{array}{c}\text { Inland } \\
\text { connection } \\
\text { system }\end{array}$ & $\begin{array}{c}\text { Terminal } \\
\text { productivity }\end{array}$ & $\begin{array}{c}\text { Economical } \\
\text { efficiency }\end{array}$ & $\begin{array}{c}\text { Service } \\
\text { level }\end{array}$ & $\begin{array}{c}\text { Tochnology } \\
\text { application }\end{array}$ \\
\hline $\begin{array}{c}\text { Gate } \\
\text { system }\end{array}$ & 0.494 & 0.494 & 0.494 & 0.494 & 0.494 & 0.494 & 0.494 & 0.494 \\
\hline $\begin{array}{c}\text { Yard } \\
\text { system }\end{array}$ & 0.223 & 0.223 & 0.223 & 0.223 & 0.223 & 0.223 & 0.223 & 0.223 \\
\hline $\begin{array}{c}\text { Shipment } \\
\text { system }\end{array}$ & 0.172 & 0.172 & 0.172 & 0.172 & 0.172 & 0.172 & 0.172 & 0.172 \\
\hline $\begin{array}{c}\text { Inland } \\
\text { connection }\end{array}$ & 0.112 & 0.112 & 0.112 & 0.112 & 0.112 & 0.112 & 0.112 & 0.112 \\
\hline $\begin{array}{c}\text { system } \\
\text { Sub total }\end{array}$ & 1.000 & 1.000 & 1.000 & 1.000 & 1.000 & 1.000 & 1.000 & 1.000 \\
\hline $\begin{array}{c}\text { Teminal } \\
\text { productivity }\end{array}$ & 0.539 & 0.539 & 0.539 & 0.539 & 0.539 & 0.539 & 0.539 & 0.539 \\
\hline $\begin{array}{c}\text { Economical } \\
\text { efficiency }\end{array}$ & 0.186 & 0.186 & 0.186 & 0.186 & 0.186 & 0.186 & 0.186 & 0.186 \\
\hline $\begin{array}{c}\text { Service } \\
\text { application }\end{array}$ & 0.178 & 0.178 & 0.178 & 0.178 & 0.178 & 0.178 & 0.178 & 0.178 \\
\hline $\begin{array}{c}\text { Sub total } \\
\text { Sechnology }\end{array}$ & 1.000 & 1.000 & 1.000 & 1.000 & 1.000 & 1.000 & 1.000 & 1.000 \\
\hline & 0.097 & 0.097 & 0.097 & 0.097 & 0.097 & 0.097 & 0.097 \\
\hline
\end{tabular}

3) Decision for detailed priority of detailed evaluation items

Detailed evaluation items in every criteria have been analyzed and these items are listed; handling ability per hour and facility rehandling ratio in the terminal productivity, yard space utilization and terminal operation cost in economic efficiency, rapidity and timely, providing information, security and custom in service level, and spreading technology effects and impact of work improvement in technology application. The result is shown in Table 9. 
Table 9 Relative priorities with respect to evaluative sub-criteria of RFID

\begin{tabular}{c|c|c|c|c|c|c|c}
\hline \multicolumn{2}{c|}{ Terminal productivity } & \multicolumn{2}{|c|}{ Fonomical efficiency } & \multicolumn{2}{c|}{ Servioe level } & \multicolumn{2}{c}{ Technogy apdicalion } \\
\hline $\begin{array}{c}\text { Detailed } \\
\text { items }\end{array}$ & Priority & $\begin{array}{c}\text { Detailed } \\
\text { items }\end{array}$ & Priority & $\begin{array}{c}\text { Detailed } \\
\text { items }\end{array}$ & Prority & $\begin{array}{c}\text { Detailed } \\
\text { items }\end{array}$ & Priority \\
\hline $\begin{array}{c}\text { Handling } \\
\text { ability }\end{array}$ & 0.791 & $\begin{array}{c}\text { Space } \\
\text { utilization }\end{array}$ & 0.727 & $\begin{array}{c}\text { Rapid } \\
\text { response }\end{array}$ & 0.648 & $\begin{array}{c}\text { Spreading } \\
\text { technology }\end{array}$ & 0.392 \\
\hline $\begin{array}{c}\text { Rehandling } \\
\text { ratio }\end{array}$ & 0.209 & $\begin{array}{c}\text { Operation } \\
\text { cost }\end{array}$ & 0.273 & $\begin{array}{c}\text { Providing } \\
\text { information }\end{array}$ & 0.184 & $\begin{array}{c}\text { Business } \\
\text { improvement }\end{array}$ & 0.608 \\
\hline & & & & Security & 0.167 & & \\
\hline Total & 1.000 & Total & 1.000 & Total & 1.000 & Total & 1.000 \\
\hline
\end{tabular}

\section{4) Analysis result of ANP Model}

As processing 3 steps of ANP analysis, the evaluation criteria and priority of detailed evaluation items to draw an application field of RFID have been shown in Fig. 8.

Above all, Gate system for applying RFID in the container terminal is the most important as resulted $49.4 \%$, and next one is yard system expected $22.3 \%$, shipment system $17.2 \%$, and inland connection system $11.2 \%$, as important as resulted their priority. The priority of evaluation criteria to evaluate those application field has been calculated that terminal productivity is $53.5 \%$, economic efficiency is $18.6 \%$, service level is $17.8 \%$ and technology application is $9.7 \%$. The last, relative priority of detailed evaluation items marked the handling capacity per hour(42.5\%), yard space utilization(13.5\%), rapidity and timely $(11.5 \%)$ and facility rehandling ratio(11.3\%) in order. This result indicates that terminal productivity (handling ability per hour and facility rehandling) should be considered applying RFID in the container terminal among many factors. The importance of each RFID application fields in the container terminal has been inspected that gate system is the most important as $49.4 \%$, yard system $22.3 \%$, shipment system $17.2 \%$, and inland connection system $11.2 \%$ in order. For appraising those application field, priority of evaluation criteria shows that terminal productivity $53.5 \%$, economic efficiency $18.6 \%$, service level $17.8 \%$ and technology application $9.7 \%$ have been seen with their importance value.

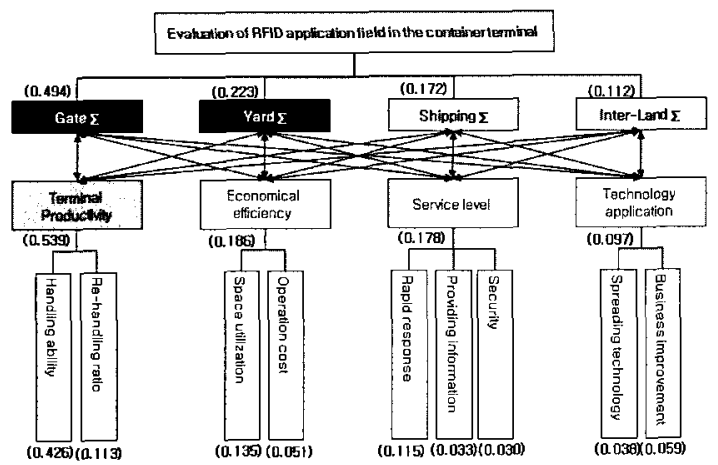

Fig. 9 Result of an evaluation on application field of RFID in container terminal by ANP

\section{Conclusion}

In this paper, a technology trends of RFID and current business situation of overseas have been studied since RFI takes an important role in changes of maritime port business. Moreover, this paper has been tried to find a possible application field of RFID and its appraisal standard through reviewing prior studies and evaluate RFID application field in the container terminal by ANP analysis.

Among the various aspects, it is recognized that the Gate system activates initial data and is the inception of the terminal productivity. Also, it is important that undesirable operation of Gate system and occurring congestion may affect a traffic congestion and the terminal yard system(Kim and Kim, 2006). For the priority of evaluation criteria to figure out RFDI application field, it is resulted that productivity is the most important since productivity is essential for container terminal operating system or adding extra equipments for work. Besides, the handling ability per hour is the most important factor among the detailed items of productivity. Those results show that productivity per hour , space utilization in the yard and equipment rehandling should have priority, though RFID and $\mathrm{e}^{-}$-Seal are a worldwide trends. On the other side of understanding, the reason that Gate system is inspected as the most important application field, is that RFID show business has been setup and managed based on Gate RFID. Moreover, the container information is delivered in advance through the RFID, and rehandling ratio is actually reduced those jobs for loading and carrying out in the yard.

Besides, RFID application field can be evaluated according to the business area of expert and it may effect on priority of evaluation criteria. Therefore, it may need to distinguish the business area of expert and perform an additional ANP analysis. If we are able to do a simulation for every part of the container terminal based on actual data from RFID show business (which sponsored by ministry of maritime affairs and fisheries), it will be brought more practical and high applicable results.

\section{References}

[1] CHEN, T. (1999), "Yard Operation in Container terminal- a study in the 'unproductive moves", Maritime Policy. Vol26, No1, pp27-38.

[2] Gribson, R., Carpenter, B., and Seeburger, S.(1996). "A flexible Port Traffic Planning Model" Proceedings of the 1996 Winter Simulation conference.

[3] Hamalainen, R. P. and Stepplinen, T. O. (1986), "The 
Analytic Network Process in Energy Polish Planing," Socio-Economic Planing Sciences, Vo.. 20, pp. 99-105.

[4] Hong, D. H. and Chung, T. C. (2003), "Designing of gate structure and optimal operation system in automated port", Korea information processing societyA Vol.10-A, No.5, pp.513-518.

[5] Kim, W. S. and Nam, K. C. (1998), "Planning of simulation system for improving container terminal operation", Korean Institute of Navigation and Port Research '98 autumn proceeding, pp.125-135.

[6] Kim, Y. S., Lee, H. G., and Shin, C. H. (2004), “A Study on port selection criteria", Korean Institute of Navigation and Port Research, Vol.28, No.6, pp.525-530.

[7] $\mathrm{KDI}(2000)$, "A study of standard guide for preliminary verification in the port business".
[8] Kim, H. and Kim, Y. S. (2006), "A study on efficient gate system based RFID at the container terminal", Korean Institute of Navigation and Port Research, Vol.30, No.4, pp.277-283.

[9] Lee, Y. L., Seo, H. S., and Yun, D. K. (2004), "Designing of Customer-oriented Marketing Decision Model by ANP", The korean society for quality management, Vol.33, No. 2, pp.31-39.

[10] Mead, L. M. and Joseph, S. (2002), "A Conceptual Model for Selection and Evaluating Third party Reverse Logistics Provider," Supply Chain Management, An International Journal, Vol. 7(5), pp. 283-295.

[10] Saaty, T. L.(1996), "Decision Making with Dependence and Feedback; The Analytic Network Process," RWS Publications, Pittsbrugh, PA.

Received 25 July 2007

Accepted 19 Setpember 2007 